\title{
Global Anti-Anarchism: The Origins of ideological Deportation and the Suppression of Expression
}

Julia Rose Kraut

New York University

Follow this and additional works at: https://www.repository.law.indiana.edu/ijgls

Part of the Immigration Law Commons, and the International Law Commons

\section{Recommended Citation}

Kraut, Julia Rose (2012) "Global Anti-Anarchism: The Origins of ideological Deportation and the Suppression of Expression," Indiana Journal of Global Legal Studies: Vol. 19 : Iss. 1 , Article 7. Available at: https://www.repository.law.indiana.edu/ijgls/vol19/iss1/7

This Symposium is brought to you for free and open access by the Law School Journals at Digital Repository @ Maurer Law. It has been accepted for inclusion in Indiana Journal of Global Legal Studies by an authorized editor of Digital Repository @ Maurer Law. For more information, please contact rvaughan@indiana.edu.

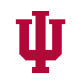

JEROME HALL LAW LIBRARY INDIANA UNIVERSITY Maurer School of Law
Bloomineton 


\title{
Global Anti-Anarchism: The Origins of Ideological Deportation and the Suppression of Expression
}

\author{
JULIA ROSE KRAUT*
}

\begin{abstract}
On September 6, 1901, a self-proclaimed anarchist named Leon Czolgosz fatally shot President William McKinley at the Pan-American Exposition in Buffalo, New York. This paper places the suppression of anarchists and the exclusion and deportation of foreigners in the aftermath of the "shot that shocked the world" within the context of international anti-anarchist efforts, and reveals that President McKinley's assassination successfully pulled the United States into an existing global conversation over how to combat anarchist violence. This paper argues that these anti-anarchist restrictions and the suppression of expression led to the emergence of a "free speech consciousness" among anarchists, and others, and to the formation of the Free Speech League, predecessor of the American Civil Liberties Union (ACLU). Challenging governmental suppression transformed anarchists' identities from violent criminals to free speech defenders. This paper also explores the history, passage, and implementation of the Alien Immigration Act of 1903, which barred and expelled anarchists, those associated with anarchists, and those advocating anarchism, and became the first federal law authorizing the exclusion or deportation of foreigners based on their ideological beliefs, associations, and/or expressions. In United States ex rel. Turner v. Williams (1904), the Supreme Court affirmed the deportation of British philosophical anarchist John Turner and upheld

* Ph.D. candidate, New York University's History Department; J.D. magna cum laude, Order of the Coif, American University's Washington College of Law; B.A. magna cum laude, Phi Beta Kappa, Columbia University. I write on American radicalism and American legal history, including immigration and First Amendment law. My dissertation is entitled: "Fearing Foreigners and Freedom: Ideological Exclusion and Deportation in America." I would like to thank Professor Alfred Aman and the Indiana Journal of Global Legal Studies for the opportunity to participate in the Globalization and Migration Symposium. I would also like to thank my advisor Professor Thomas Bender for his guidance and encouragement and my friends and family for their support.
\end{abstract}

Indiana Journal of Global Legal Studies Vol. 19 \#1 (Winter 2012) (C) Indiana University Maurer School of Law 
the Alien Act's constitutionality, establishing the precedent for future ideological restrictions of foreigners. This legal precedent paved the way for the mass deportations of radicals after the 1919 Palmer Raids, the exclusion of alleged communist writers, actors, and professors under the McCarran Act of 1950 and the McCarran-Walter Act of 1952, and eventually for a visa denial barring entry to an Islamic scholar under the Patriot Act of 2001.

\section{INTRODUCTION}

On September 6, 1901, President William McKinley greeted visitors at the Pan-American Exposition in Buffalo, New York. One of the last to greet him was Leon Czolgosz. Extending his hand, wrapped in a handkerchief, Czolgosz reached to shake McKinley's hand. But, the handkerchief concealed a revolver, and before the men's hands met, he had fired twice into the President's chest. The Secret Service immediately apprehended Czolgosz. The gunshots, however, did not immediately kill McKinley, who died a week later, having succumbed to gangrene. ${ }^{1}$

The troubled Czolgosz claimed he was a disciple of the notorious anarchist leader and lecturer Emma Goldman. ${ }^{2}$ He had once briefly met Goldman after one of her lectures. ${ }^{3}$ Czolgosz explained that he had plotted alone, but that Goldman's speeches had set him "on fire."4 In the initial aftermath of the assassination, men and women harassed and attacked anarchists and those they suspected of being unpatriotic. One

1. See Murat Halstead, The Illustrious Life of William McKinLEy 37-45 (1901). See also Boston Witness's Story. Says President Prayed that Assassin Might Be Forgiven, N.Y. TIMES, Sept. 8, 1901, at 2.

2. Emma Goldman (1869-1940) immigrated to the United States from Lithuania in 1885. She became "radicalized" during the Haymarket Affair in 1886 and became an anarchist. She met anarchists Alexander Berkman and Johann Most, becoming Most's protégé, and began lecturing on anarchism during the $1890 \mathrm{~s}$. By 1901, she had replaced Johann Most as the leader of the anarchist movement in America. See generally ALICE WEXLER, EMMA GOLDMAN IN AMERICA (1984).

3. See 1 Emma Goldman, LIVING MY LiFe 289-91 (Dover Publ'ns 1970) (1931) (describing meetings with Czolgosz, who had used the name "Fred Nieman"). Czolgosz was not considered part of the anarchist community or recognized as Goldman's disciple, and thus, would be most appropriately characterized as a self-proclaimed anarchist. After the assassination, anarchist leader Johann Most explained that Czolgosz was not known among anarchists, calling him a "crank or downright crazy." See Anarchists Don't Know Him. Herr Most and Justus H. Schwab Say Nieman is Not a Member of the Reds, N.Y. TIMES, Sept. 7, 1901, at 5. The editor of the anarchist newspaper Free Society suspected Czolgosz was a spy upon first meeting him; he later publicly apologized for suspecting Czolgosz. See Why We Considered Czolgosz a Spy, FREE Soc'Y, Oct. 6, 1901 at A1.

4. The Assassin Makes a Full Confession, N.Y. TIMES, Sept. 8, 1901, at A1. 
man urged a crowd to go over to Paterson, New Jersey and "exterminate" the anarchists there..$^{5}$ Another refused to march under an American flag, and a mob formed to lynch him. "Anarchist" quickly became a caustic epithet, often provoking violent responses. ${ }^{7}$ After a few weeks, these public displays of patriotism and acts of vengeance subsided. However, many Americans had started to call on their government and turn to the law to protect them against this perceived new anarchist threat at home and an imagined threat from foreign anarchists abroad. 8

In the years following the "shot that shocked the world,"9 Congress, state legislatures, and law enforcement attempted to suppress anarchist activities, relying on current laws and passing new ones, including immigration restrictions on foreign anarchists. While many Americans considered anarchism a foreign problem and the United States immune from the litany of anarchist assassinations of European leaders and monarchs in the 1890s, President McKinley's assassination pulled the United States into existing international efforts and the global conversation about how to combat anarchist violence.

As the United States entered the "War on Anarchy,"10 it also adopted some European anti-anarchist tactics including exclusion and deportation and the suppression of anarchist speech. Yet these tactics and attempts to eject, muzzle, and repress anarchists backfired. Instead, they succeeded in uniting and galvanizing anarchists and others in a common recognition that such suppression threatened freedom of speech, and they helped raise a "consciousness"11 of the

5. Wanted to Kill Anarchists, N.Y. Times, Sept. 7, 1901, at A1. Paterson, New Jersey was known as a "hot bed" for Italian anarchists. Italian anarchist Gaetano Bresci lived in Paterson prior to his return to Italy to assassinate King Humbert I in 1900. See Assassin of Humbert Goes on Mission from America, CHI. DAILY TRIB., July 31, 1900, at 1.

6. HALSTEAD, supra note 1 , at 84 .

7. See Called Anarchist; Used Razor, N.Y. TIMEs, Sept. 12, 1901, at 2 (describing two men, one man calling the other an anarchist, and the other man cutting him with a razor in response).

8. See No Evidence Against Emma Goldman, N.Y. TTMES, Sept. 13, 1901, at 1.

9. While the description the "shot that shocked the world" had been used before to describe President Lincoln's assassination, the phrase appears to have been applied to McKinley's assassination as well. See EDWARD LEIGH PELL ET AL., A MEMORIAL VoluME OF AMERICAN HISTORY: MCKINLEY AND MEN OF OUR TIMES 189 (1901).

10. Nation's War on Anarchy Begins, CHI. DAILY TRIB., Sept. 11, 1901, at 2.

11. See David Thelen, Introduction to Symposium, The Constitution and American Life, Part II: Rights Consciousness in American History, 74 J. AM. HIST. 793, 795 (1987) (describing rights consciousness as the struggle of dispossessed persons to possess constitutional rights denied to them). According to Thelen; this struggle has influenced these groups' identities and 'translated their organizing visions into a language of rights, and then they have sought to use-and sometimes to change-law and the Constitution to secure those rights." Id. For the purposes of this paper, I define consciousness a bit more 
importance of preserving and protecting this freedom. Ultimately, this suppression and deportation transformed anarchists' identities and the public's perception of anarchists from dangerous, violent criminals to free speech defenders.

While exclusion and deportation are often relegated to a category of immigration law, the ideological restriction of foreigners (i.e., restrictions based on belief, advocacy, or association) presents a unique intersection of immigration and First Amendment law and history. Legal scholars and historians have long neglected the origins of ideological restrictions and this period of anti-anarchist fervor. ${ }^{12} \mathrm{~A}$ closer examination of the suppression of anarchism and legal exclusion and deportation of foreign anarchists, as well as the response to this suppression and such restrictions, reveals the significance of this transnational moment in American social and legal history, and its legacies throughout the twentieth century and the global War on Terror.

\section{ANARCHISM AND VIOLENCE IN AMERICA AND ABROAD}

Emma Goldman defined anarchism as "the philosophy of a new social order based on liberty unrestricted by man-made law; the theory that all forms of government rest on violence, and are therefore wrong and harmful, as well as unnecessary."13 Yet, popular conceptions of

broadly. Rather than limiting rights consciousness to a particular dispossessed group, my focus is on free speech consciousness as the recognition and struggle for constitutional rights threatened or denied. This consciousness arises among a diverse group of people, including members of the press, progressive reformers, radicals, and nonradicals, as well as anarchists, even if the anarchists' identities are the most influenced and transformed by their struggle and this consciousness.

12. Legal scholars and historians either ignore this period entirely or treat it briefly, focusing only on specific laws and challenges, such as the Alien Immigration Act of 1903 and United States ex rel. Turner v. Williams, 194 U.S. 279 (1904). They often fail to touch upon the response of anarchists and others to repression, or upon the emergence of free speech consciousness. See, e.g., WILlLIAM PREston JR., ALIENS AND DISSENTERS: FEDERAL SUPPRESSION OF RADICALS, 1903-1933, at 25-34 (2nd ed. 1963); HARRY KALVEN, JR., A WORTHY TRADITION: FREEDOM OF SPEECH IN AMERICA 437-48 (1988); DAVID COLE, ENEMY Aliens: Double STANDARDS AND CONSTITUTIONAL FreEdoms IN THE WAR ON TERRORISM 107-09 (2003); DANIEL KANSTROOM, DEPORTATION NATION: OUTSIDERS IN AMERICAN History 136-37 (2007). But see DAVID RABBAN, FREE SPEECH IN ITS FORGOTTEN YEARS 4476, 143-44 (1997) (including more discussion of Turner and of the suppression of anarchists after McKinley's assassination, but focusing more on Theodore Schroeder and the Free Speech League than on the anarchists and locating the emergence of free speech consciousness a few years later with the Industrial Workers of the World free speech fights from 1909 to 1913).

13. EMMA GOLDMAN, Anarchism: What it Really Stands for, in ANARCHISM AND OTHER EsSAYS 53, 56 (Kennikat Press 1969) (1910). 
anarchism held that violence stemmed from the anarchists themselves, and not government.

By 1901, there were two types of anarchists: philosophical and violent. ${ }^{14}$ Philosophical anarchists advocated for the abolition of all organized government, attended anarchist meetings, read anarchist newspapers, and listened to anarchist lectures. Violent anarchists, like Czolgosz, not only advocated for an overthrow of government, but also took action to effect it, including through bombings and assassination. ${ }^{15}$ While the vast majority of anarchists were philosophical anarchists, by 1901, most members of the American public reading about anarchist activities would have viewed all anarchists as dangerous assassins and bomb-throwers. ${ }^{16}$ The 1880 s and 1890 s had brought anarchist violence to the forefront of public attention with the Haymarket Affair in 1886,17 anarchist Alexander Berkman's attempt to assassinate Henry Clay Frick in 1892,18 and a slew of anarchist assassinations in Europe. Anarchists assassinated French President Marie François Sadi Carnot in 1894, Spain's Prime Minister Antonio Cánovas del Castillo in 1897, Austrian Empress Elisabeth in 1898, and King Umberto I of Italy in 1900.19

This series of assassinations and attempted assassinations by anarchists would not only contribute to Americans' perception of

14. There are many distinctions between anarchists. The category includes individualist "homegrown" American anarchists in the United States, such as Josiah Warren and Benjamin Tucker. However, it also includes communist "foreign" anarchists such as Pierre-Joseph Proudhon, Peter Kropotkin, Mikhail Bakunin, and Johann Most who advocated "propaganda by deed." See generally PAUL AVRICH, ANARCHIST PORTRAITS (1988) (providing biographies of most of these anarchists and detailing their beliefs and their experiences propagating anarchism in the United States). For the purposes of this paper, I have adopted a distinction emerging in the late nineteenth century articulated by historian Sidney Fine. See SIDNEY FINE, ANARCHISM AND THE ASSASSINATION OF MCKINLEY, 60 AM. HIST. REV. 777, 778-80 (1955).

15. See FINE, supra note 14 , at 780 .

16. See id. at 778 ("The popular view of anarchism and anarchists was, to a considerable extent, the product of a series of spectacular acts of violence perpetrated by, or attributed to, anarchists in Europe and the United States in the last quarter of the nineteenth century.").

17. On May 4, 1886, a bomb exploded in Haymarket Square in Chicago during a labor demonstration, killing and wounding several people, including a police officer. Eight anarchists were arrested and convicted, despite little evidence and no identification of the specific man who allegedly threw the bomb. Many believed that their convictions were miscarriages of justice. Four of the convicted anarchists were executed. In 1893, Illinois Governor John P. Altgeld issued a pardon for the remaining Haymarket anarchists. See PAUL AVRICH, THE HAYMARKET TRAGEDY 418-27 (1986).

18. Shot in His Office: Attempted Assassination of Mr. Henry C. Frick, WASH. Post, July 24,1892 , at 1.

19. See FINE, supra note 14 , at 779 . 
anarchists as violent criminals, terrorizing Europe and killing its leaders, but also as foreigners. Shortly after McKinley's assassination, The New York Times reported that many American police forces were unfamiliar with anarchists, asserting "they did not know there were any here."20 Although shocked to learn that Leon Czolgosz was an anarchist and an American, born in Detroit, Michigan, newspapers described Czolgosz as having a foreign-sounding name and identified him as the son of immigrants. ${ }^{21}$ Thus, with the assassination of President McKinley, this "foreign problem" had become an American one.

In reaction to each assassination, nations across Europe, including Germany, Russia, France, Italy, Spain, and Switzerland, arrested anarchists, and called for the suppression of anarchist newspapers. ${ }^{22}$ Many, like France and Spain, expelled anarchists from their borders. ${ }^{23}$ There were raids and arrests of anarchists, expulsions, and reforms in laws, including extradition of anarchists and broad, sweeping provisions to deport anarchists at will: ${ }^{24}$ These expulsions proved problematic because many nations refused to accept these undesirable refugees, and anarchists often sought asylum in England or the United States. ${ }^{25}$

Some warned the United States of its failure to wage its own war against anarchists, lest "[we] allow our country to be made the dumping-ground for all the vile brood of Anarchists and criminals in the fetid atmosphere of European vice and oppression." 26 The United States, however, did not pass any restrictions on anarchist newspapers, anarchist lectures, or foreign anarchists. ${ }^{27}$ Nor did the United States participate in the first international Anti-Anarchist Conference held in Rome in November 1898. ${ }^{28}$ For several weeks, delegates from every European nation discussed various methods to

20. Physicians Declare That Czolgosz Is Sane, N.Y. TIMES, Sept. 10, 1901, at A1 (describing police as having never given U.S. anarchists serious consideration).

21. See Assassin Known as a Rabid Anarchist, N.Y. TIMES, Sept. 8, 1901, at 4.

22. See, e.g., Anarchist Hunt in France, N.Y. TRIB., Feb. 20, 1894, at 5; Anarchist Hunt in Spain, WASH. Post, Sept. 29, 1893, at 1; Europe Declares War on Anarchy, S.F. ChRON., Sept. 12, 1898, at 1 .

23. See Anarchist Prisoners in Montjuich, N.Y. TRIB., Aug. 15, 1897, at 2; The AntiAnarchist Bill, IRISH TIMES, July 26, 1894, at 5.

24. See The Anarchists in Germany, N.Y. TIMES, July 30, 1894, at 9.

25. See Anarchist Prisoners in Montjuich, supra note 23, at 2.

26. Anarchists Must Go, L.A. TIMES, Oct. 9, 1898, at 2.

27. See infra Section III. There was one attempt to pass federal legislation to expel or deport foreign anarchists in 1894, called the "Hill Bill," but it died in debate in the House of Representatives.

28. See Anti-Anarchist Conference: It was Opened at Rome with Many Nations Represented, N.Y. TIMES, Nov. 25, 1898, at 5. 
combat the anarchist threat, including the formation of an international police bureau to conduct investigations and open communication among nations to track anarchist activities. Each nation also considered recommendations to pass legislation to suppress the anarchist press and prevent violence. ${ }^{29}$

In the immediate aftermath of President McKinley's assassination, Russia and Germany agreed to completely suppress all anarchist newspapers. ${ }^{30}$ Italian authorities renewed their anti-anarchist efforts, suppressing anarchist meetings and arresting individual anarchists. France vowed to ban all anarchist literature, philosophical and otherwise, and Swiss authorities intended to pass more stringent antianarchist laws. ${ }^{31}$ In Germany, Imperial Chancellor Count von Bulow announced that anarchists would be under constant surveillance, subject to arrest and deportation at any time if suspected of contributing to labor unrest or for their unruly behavior. ${ }^{32}$ While these European nations condemned McKinley's assassination and welcomed the United States into the War on Anarchy, they did so with a slight tinge of schadenfreude toward these American latecomers:

Europe has already done so much to check Anarchism that it can now leave the problem to the Americans, who are an eminently practical people and doubtless devise means of rooting out the evil in their own country. Europe will look with the greatest interest to the inauguration of such a crusade, and will doubtless learn something to its own advantage. ${ }^{33}$

President McKinley's assassination had thrust the United States into the War on Anarchy. No longer an exception to anarchist violence, the United States had become a "nation among nations" 34 tackling the anarchism problem. It was time to get to work. It was America's turn to take action.

29. See Anti-Anarchist Conference: Result of the Deliberations, IRISH TIMES, Dec. 26, 1898, at 5; Anti-Anarchists Confer, L.A. Times, Dec. 29, 1898, at 11.

30. European Measures Against Anarchism, N.Y. TLMES, Sept. 24, 1901, at 2.

31. See Propaganda of Death, WASH. POST, Oct. 6, 1901, at 16.

32. Id.

33. See Interest in Germany Keen, N.Y. TIMES, Sept. 11, 1901, at 2 (quoting the German newspaper the COLOGNE GAZETTE).

34. See generally Thomas Bender, A Nation among Nations: America's Place in WORLD HISTORY (2006) (asserting that one cannot fully understand American history without placing America within a global context). 


\section{TURNING TO THE LAW: SUPPRESSION OF EXPRESSION AND THE BIRTH OF THE FREE SPEECH LEAGUE}

In the wake of President McKinley's assassination, one of the greatest obstacles to the fight against anarchism in the United States was that there were no specific antianarchy laws in effect, so law enforcement had to use existing laws in initial efforts. So-called breach of the peace and unlawful assembly statutes under state police powers served as the legal basis to raid anarchist meetings, break up lectures, and suppress anarchist newspapers. Shortly after Czolgosz shot McKinley, New York City police arrested Johann Most, ${ }^{35}$ an internationally renowned anarchist leader and the editor of German anarchist newspaper Freiheit (Freedom). The September 7 issue of Freiheit included excerpts from "Mord contra Mord" ("Murder versus Murder"), an essay written by German Revolutionary Karl Heinzen in 1849 and later reprinted in Freiheit in 1885. The passages included statements such as "[d]espots are outlaws ... to spare them is a crime . . .. [w]e say murder the murderers. Save humanity through blood and iron, poison and dynamite." 36 When Most heard of President McKinley's assassination, he immediately pulled the issue, but a few early editions had already been released. ${ }^{37}$ Although there was no evidence linking any disturbance, crime, or violence to articles in Freiheit, Most was convicted of breach of the peace in New York and sentenced to one year in prison. ${ }^{38}$

This decision also revealed that anti-anarchist sentiment had penetrated the judiciary. One judge insisted that anarchists and their speech did not deserve constitutional protection. He declared:

It was said by a distinguished English judge, in the celebrated Somerset slave case, that 'No slave can breathe the free air of England.' It would be well if the laws of this country were such that it could be said truthfully, that no anarchist can breathe the free air of America. ${ }^{39}$

35. John Most is Again Arrested, N.Y. TIMES, Sept. 23, 1901, at 1.

36. FINE, supra note 14 , at 783 .

37. Id.

38. People v. Most, 73 N.Y.S. 220, 224 (Ct. Spec. Sess. 1901); see also People v. Most, 75 N.Y.S. 591, 592 (App. Div. 1902).

39. Most, 73 N.Y.S. at 224; see also Most, 75 N.Y.S. at 592. 
The Court of Appeals upheld Most's conviction under the Blackstonian bad tendency test, ${ }^{40}$ finding his publication fell outside New York state constitutional free speech protections. Because Freiheit might have the tendency to harm the public, "it [was] not necessary to trace and establish the connection between the teaching of anarchy and a particular crime of an overt nature." 41

Continuing their efforts to suppress anarchist newspapers, law enforcement officials also attempted to shut down a newspaper called Discontent, published in the anarchist community in Home Colony, Washington. ${ }^{42}$ This time, law enforcement used existing federal law, arresting editors and contributors to the newspaper for "depositing, lewd, lascivious and obscene literature in the mails" in violation of the Comstock Act. ${ }^{43}$

Anarchists rallied to support those arrested, publishing their appeals in other anarchist newspapers like Moses Harman's Lucifer: the Lightbearer, where they also began to establish a defense fund and denounced the use of the Comstock Act as a guise to suppress anarchism by deeming it obscene. ${ }^{44}$ In the pages of Lucifer, anarchists discussed the possibility of forming a free speech organization, reaching beyond the anarchist suppression. The new organization would seek "to maintain the right of free speech against all encroachments." 45 On May 1, 1902, anarchists founded the Free Speech League. The birth of the League had come just in time.

A month earlier, the New York state legislature had passed the Criminal Anarchy Act, which explicitly made anarchist expression illegal. Under this law, it was a felony to "advocate, advise, teach, print,

40. At this time, jurisprudential understandings of free speech derived from the English Common Law conceptions of free speech purported by Sir William Blackstone in his Commentaries on the Laws of England (1769). Blackstone considered the right of free speech as precluding prior restraints, but not as precluding restrictions on speech that had the "tendency" to harm the public welfare. Blackstone was not concerned with results, but rather the provocation of harm. Thus, courts relied on the "bad tendency" test to determine protected and unprotected speech. Speech that possessed a "natural and probable tendency" to produce violence or immorality was not protected by the First Amendment or any state Constitutional provision protecting free speech. See also RABBAN, supra note 12 , at 38 .

41. Most, 73 N.Y.S. at 222; see also People v Most, 171 N.Y. 423, 430 (Ct. App. 1902).

42. See generally Candy Hatcher, No Place Like Home, SEATTLE POST-INTELLIGENCER, Dec. 18, 2000, available at http://o.seattlepi.com/local/ever18.shtml.

43. James F. Morton, Jr., To the Liberal Public, DiscontenT, Nov. 13, 1901, at 1.

44. Id.; Edward Chamberlain, What is the United States Constitution Worth, Discontent, Nov. 20, 1901, at 1.

45. James F. Morton, Jr., The Wise Case, DisconTENT, Dec. 11, 1901, at 1 (discussing formation of an organization); see also A Call for Concerted Action, LUCIFER: THE LIGHTBEARER, May 1, 1902, at 122-23 (describing the League's intentions). 
publish, edit, circulate, sell, or publicly display" anything having to do with anarchism. If convicted, one faced ten years in prison or a $\$ 5,000$ fine. ${ }^{46}$ Considered by anarchists, radicals, and progressives to be an assault on philosophical beliefs and a blatant disregard for free speech, New York's Criminal Anarchy Act would become a rallying cry to gain support and raise money for the Free Speech League to defend those prosecuted under it. ${ }^{47}$

\section{THE 1903 ALIEN IMMigRATION ACT: THE HILl BILl REVISITED}

If the lack of antianarchy laws at the time of President McKinley's assassination upset fearful Americans, the absence of such laws proved embarrassing to members of Congress, who recalled an antianarchy bill that died in debate a few years earlier. ${ }^{48}$ After an anarchist successfully assassinated French President Carnot in 1894, members of Congress feared that these dangerous foreign anarchists would seek refuge in the United States, bringing their hatred of government and their desire to continue terrorist activities with them. One concerned congressman announced, "We are advised that a large number of the most dangerous anarchists in the world are now on their way to the United States, and that at this time there is no law on the statute books which prohibit the landing of an anarchist in this country." 49 Within two months of President Carnot's assassination, Republican New York Senator David B. Hill had sponsored a bill that would exclude anarchists from entry to the United States and provide for the deportation of unnaturalized anarchists. It was referred to as the "Hill Bill." 50

There was much support for this bill in the House of Representatives and the Senate, and many pressed for the swift passage of the Hill Bill. During debate, Senator Hill noted that English anarchist Charles Mowbray had entered the United States and was currently delivering a series of lectures on anarchism to crowds of people in various cities including Chicago, New York, Philadelphia, and Boston. ${ }^{51} \mathrm{He}$ lamented that the United States not only lacked laws to prevent Mowbray from entering the country, but also laws to permit his

46. See N.Y. Penal Law § 468(a).(e) (Consol. 1910). See also N.Y. Penal Law § 161 (Consol. 1918).

47. See The "Criminal Anarchy" Law, MOTHER EARTH, Dec. 10, 1906, at 10.

48. See A Senate Bill to Keep out Anarchists, N.Y. DAILY TRIB., Sept. 11, 1901, at A3 (discussing the "Hill Bill," which passed in the Senate but died in debate in the House of Representatives).

49. 26 CONG. REC. 8628 (1894) (statement of Rep. Charles Boatner (D-LA)).

50. See Deportation of Anarchists: The Hill Bill Amended by the House Judiciary Committee, WASH. POST, Dec. 15, 1894, at 7.

51. See 26 CoNG. REC. 8238 (1894) (statement of Sen. David B. Hill (R-NY)). 
expulsion.52 The United States was thus powerless to stop the infiltration of foreign anarchists and the spread of their ideology.

Over the course of these debates, however, many members of Congress expressed concern and were reluctant to pass the Hill Bill. The main problem was that the bill did not include the definition of an "anarchist." Senator Hill insisted that one was unnecessary, ${ }^{53}$ but others disagreed. Some argued that without a definition many foreigners who did not pose a threat to the United States would be excluded or deported. Immigration officials enforcing the provisions of the Hill Bill could exclude anyone under the guise of being an anarchist, including socialists and philosophers who posed no actual threat to Americans or to their government. ${ }^{54}$

Massachusetts Republican Senator George F. Hoar also questioned the legitimacy of excluding anarchists, describing such exclusion as arbitrary and contrary to American values of freedom, including the right to travel and to emigrate. He stated:

It is one of the chief glories of the Republic itself . . that a human being anywhere might lay down one nationality and take upon himself another ... [t]he pending bill says ... not that a man has done anything, not even that he has said anything, but that he is a character defined by the vague, indeterminate word "anarchist" ... he shall be excluded and sent back to the country whence he came. ${ }^{55}$

When an amendment to the Hill Bill added a definition of "anarchist," it raised more questions and concerns. According to Democrat New York Congressman John Dewitt Warner, who ultimately refused to pass the Hill Bill, an amendment had included a definition of "anarchist," but the definition was overbroad, barring all anarchists and all persons who objected to any particular government.56 Other members of Congress disagreed on whether a difference between "violent" and "philosophical" anarchists even existed, and whether this

52. See id.

53. Id. at 8231.

54. See, e.g., id. at 8238 (statement of Sen. John M. Palmer (D-IL)).

55. See id. at 8241 (statement of Sen. George F. Hoar (R-MA)).

56. See Mr. Warner's Course on Hill Immigration Bill, N.Y. TIMES, Sept. 23, 1901, at A2. (describing Warner's reasons for refusing to pass the Hill Bill). 
difference should be incorporated into the Hill Bill, excluding only professed violent anarchists. ${ }^{57}$

With pressure mounting, some cautioned that if Congress rushed to pass the Hill Bill without a proper definition, the members would regret it and have to deal with the consequences. ${ }^{58}$ Others argued that if Congress did not pass it, those consequences might include an assassination of a U.S. leader. ${ }^{59}$ While the Hill Bill passed in the Senate, it died in the House. For the next seven years, this attempt to exclude anarchists was forgotten.

After McKinley's assassination, one of the public's main criticisms of the United States was that Congress had not passed protective legislation to prevent the spread of anarchism and anarchist violence until it was too late. Many specifically called for exclusion and deportation restrictions on foreign anarchists and a revival of the Hill Bill. ${ }^{60}$ In 1903, Congress answered their call when it passed the Alien Immigration Act, which barred anyone who disbelieved in all organized government, who advocated or taught anarchism, or who associated with anarchists, from entry to the United States. ${ }^{61}$ To ensure passage, members of Congress insisted that the new immigration bill include the definition of "anarchist" that the Hill Bill had lacked:

[A] person who disbelieves in or who is opposed to all organized government, or who is a member of or affiliated with any organization entertaining and teaching such belief in or opposition to all organized government, or who advocates or teaches the duty, necessity, or propriety of the unlawful assaulting or killing of any officer or officers, either of specific

57. See, e.g., 26 CONG. REC. 8240 (1894) (exchange between Sen. James H. Kyle (Populist-SD) and Sen. Hill discussing the distinction between theoretical or violent anarchists and barring only the latter).

58. See id. at 8238 (statement of Sen. Palmer: "this measure is in the spirit of our fears rather than in the exercise of wise political judgment. We are agreed to punish anarchists; but it must be remembered that in our eagerness to punish the guilty we ought not to subject the innocent to danger."); Id. at 8628 (statement of Rep. John D. Warner (D-NY): "No amount of panic can scare the 'gentleman from New York' into putting into the hands of an administrative officer the detection and punishment of a crime which is not even defined in the measure which proposes to punish it by deportation.").

59. See id. at 8238 (statement of Sen. Hill: "[] $\mathrm{f}$ we discover in [the bill's] enforcement that any injustice is done to any honest class of people, it can of course be remedied. I think we are obliged to do something like this, or we shall soon witness the scenes that other countries have witnessed.").

60. See, e.g., Plans to Stamp Out Anarchy: Sentiment in Favor of Stringent Prohibitive Laws, N.Y. TimES, Sept. 10, 1901, at 2.

61. Alien Immigration Act, ch. 1012, 38 Stat. 1213, 1214 (1903). 
individuals or officers generally, of the Government of the United States or of any other organized government, because of his or their official character. ${ }^{62}$

Congress also designed the immigration bill not only to exclude alien anarchists from entering the United States, but to bar their naturalization and to allow deportation of immigrants found to be anarchists within three years after their landing. ${ }^{63}$

This ideological exclusion and deportation would join a number of immigration restrictions already in effect at this time. America had been repeatedly slamming the "golden door" 64 in the face of a variety of foreigners beginning in the 1870 s and $1880 \mathrm{~s}$. Congress barred paupers and criminals, as well as Chinese skilled and unskilled laborers from entry to the United States. ${ }^{65}$ By 1891, foreigners "likely to become a public charge" and those with "loathsome" and "contagious" diseases also were turned away. ${ }^{66}$ In 1892 , the federal government opened the largest immigration depot used to regulate immigration and implement these restrictions. In the shadow of the Statue of Liberty, inspectors on Ellis Island sifted through the massive waves of immigrants arriving each day allowing some to land and deporting the undesirable and the dangerous. In a series of challenges to the exclusions of Chinese immigrants, the Supreme Court had upheld the constitutionality of such exclusions and deportations as a part of a nation's sovereignty and right to self-preservation. ${ }^{67}$ Congress also possessed the plenary power to protect and assert this right. The judiciary could not look behind the exclusion of foreigners, but instead should defer to consular officials' determinations of which foreigner to expel and why. ${ }^{68}$

At the time, many Americans believed that exclusion and deportation of foreign anarchists was the appropriate solution to America's anarchist

62. Id. at 1221 .

63. Id. at 1218 .

64. See EMMA LAZARUS, New Colossus (1883) (describing the Statue of Liberty in New York harbor, Lazarus' sonnet depicts the statue welcoming the "wretched refuse" and "huddled masses yearning to breathe free," while she lifts the lamp "beside the golden door," interpreted as entry to America and to a new life in freedom).

65. See EDWARD P. HUTCHINSON, LEGISLATIVE HISTORY OF AMERICAN IMMIGRATION POLICY, 1798-1965, at 66, 80-81 (1981).

66. Id. at 101.

67. See Nishimura Ekiu v. United States, 142 U.S. 651, 659 (1892) (the "maxim of international law that every sovereign nation has the power, as inherent in sovereignty, and essential to self-preservation, to forbid entrance of foreigners within its dominions, or to admit them only in such cases and upon conditions as it may see fit to prescribe"). See also Lem Moon Sing v. United States, 158 U.S. 538, 544 (1895); Fong Yue Ting v. United States, 149 U.S. 698 (1893).

68. See Fong Yue Ting, 149 U.S. at 714. 
problem. ${ }^{69}$ Not only did they identify anarchism as a "foreign" ideology imported to the United States by immigrants, but they also believed that it could spread across the nation and was as dangerous as a contagious disease. ${ }^{70}$ Just like tuberculosis, anarchism could infect healthy lawabiding Americans and turn them into assassins. Thus, as a disease, anarchism had to be prevented, and the infected quarantined and expelled.

The 1903 Alien Act, however, would not satisfy all of those concerned about the anarchist threat. Some would argue the provisions were overbroad, going too far in an effort to bar and deport anarchists. The Alien Act's language and definition of "anarchist" did not make any distinction between violence and belief in a particular political philosophy. Failing to distinguish between philosophical and violent anarchists, the Act barred all from United States' shores. ${ }^{71}$ Yet, others did not think the provisions went far enough and suggested that the United States should help organize all nations into an international effort to find an island, round up all anarchists, and deport them to this island, where they could then live together without any type of organized government.72 Others found the Alien Act impracticable. Editors at The Nation magazine considered it ridiculous to question anarchists and try to root them out on Ellis Island. The editors asserted that an anarchist could simply lie during questioning and easily evade exclusion and deportation. ${ }^{73}$ The editors predicted the Alien Act would prove ineffectual. ${ }^{74}$ Perhaps they were right. Between 1904 and 1916, only twenty anarchists were excluded and deported. ${ }^{75}$ The first one was John Turner.

\section{The CASE of ENGLish ANARCHIST JOHN TURNER: THE FIRST IDEOLOGICAL DEPORTATION IN THE UNITED STATES}

John Turner was an English trades-unionist and a philosophical anarchist. In 1896, he had visited the United States on a lecture tour,

69. See Plans to Stamp Out Anarchy: Sentiment in Favor of Stringent Prohibitive Laws. At Present There Is No Provision by Which Anarchists Can Be Kept Out of the Country, N.Y. TIMES, Sept. 10, 1901, at 2.

70. See Traitors and Anarchists, N.Y. TIMES, Sept. 11, 1901, at 6.

71. See infra Section IV.

72. 35 CONG. REC. 216 (1902) (statement of Sen. Hoar submitting a resolution for an "asylum for anarchists"); see also Anarchy and its Repression, N.Y. TIMES, Aug. 18, 1906, at 7 .

73. The Bill Against Anarchists, 74 THE NATION 145, 146 (1902).

74. Id.

75. ANNUAL REPORT OF THE COMM'R GENERAL OF IMMIGRATION TO THE SEC'Y OF LABOR FOR THE FISCAL YEAR ENDED JUNE 30, 1910, at 80 (1910); ANNUAL REPORT OF THE COMM'R GENeral OF IMMIGRATION TO THE SEC'Y OF LABOR FOR THE FISCAL YEAR ENDEd JUNE 30, 1916 , at 84 (1916). 
entering the country and speaking freely. ${ }^{76}$ In 1903 , anarchists invited John Turner to come to the United States on another lecture tour and began raising money to pay for Turner's passage. ${ }^{77}$ While it does not appear that it was the anarchists' intention for Turner to test the Alien Act, it was, however, exactly what immigration officials had in mind, and they were paying close attention to Turner's upcoming visit.

Commissioner of Immigration for the Port of New York at Ellis Island William Williams had learned of Turner's upcoming visit and did in fact stop a John Turner and detain him on Ellis Island for questioning. ${ }^{78}$ Yet, it was the wrong John Turner, just an Englishman visiting the United States, who shared the same name. ${ }^{79}$ Upon this man's release, Williams hatched a plan that when the actual anarchist John Turner arrived he would be allowed to enter United States in order for officials to gather evidence against him to use in deportation proceedings under the Alien Act. ${ }^{80}$

Indeed, when John Turner arrived in October 1903, he fell into Commissioner Williams' trap, although Turner did not initially enter through Ellis Island. It was believed that he entered surreptitiously through Canada, though Turner never confirmed nor denied this method of entry. ${ }^{81}$ Turner had already commenced his lecture tour in New York City when immigration inspectors arrested him after one of his speeches and sent Turner to Ellis Island for detention pending deportation. ${ }^{82}$ These inspectors had transcribed Turner's speech, where

76. See Anarchist John Turner, WASH. Post, Apr. 24, 1896, at 6; see also Anarchists as Labor Organizers, N.Y. TRIB., June 17, 1896, at 12 (describing Turner's tour of the United States).

77. Important for New York, FrEE Soc'Y, Aug. 30, 1903, at 4.

78. Letter from William Williams, Comm'r of Immigration, Ellis Island, to F.H. Larned, Comm'r General, Bureau of Immigration (Mar. 29, 1903) (on file with the National Archives and Records Administration, Washington, D.C., contained in Immigration and Naturalization Service Record Group 85, Box 50, File 36181, Entry 7).

79. Letter from William Williams, Comm'r of Immigration, Ellis Island, to F.H. Larned, Comm'r General, Bureau of Immigration (Apr. 2, 1903) (on file with the National Archives and Records Administration, Washington, D.C., contained in Immigration and Naturalization Service Record Group 85, Box 50, File 36181, Entry 7).

80. Letter from F.H. Larned, Comm'r General, Bureau of Immigration, to William Williams, Comm'r of Immigration, Ellis Island, to (Mar. 31, 1903) (on file with the National Archives and Records Administration, Washington, D.C., contained in Immigration and Naturalization Service Record Group 85, Box 50, File 36181, Entry 7).

81. See Transcript of Record at 4, United States ex. rel. Turner v. Williams, 194 U.S. 279 (1904) (No. 561) (Warrant for Deportation of Alien No. 41324, issued by Secretary of Commerce and Labor George B. Cortelyou, dated Oct. 19,1903); see also Transcript of Record at 4, United States ex. rel. Turner v. Williams, 194 U.S. 279 (1904) (No. 561) (Testimony of John Turner from the Minutes of Board of Special Inquiry Convened at U.S. Immigration Station, Ellis Island on Oct. 23,1904).

82. Anarchists Are Raided, N.Y. TIMEs, Oct. 24, 1901, at 1. 
he identified himself as an anarchist, and they confiscated a copy of anarchist newspaper Free Society, which he had in his pocket. ${ }^{83}$ Under questioning, Turner admitted that he was an anarchist, at which point immigration officials informed him that under the 1903 Alien Act he was to be deported.84 Soon after, the Free Speech League rushed to Turner's aid. ${ }^{85}$ Pending his forced deportation, Turner was free to voluntarily leave the United States and return to England, but Emma Goldman asked him if he would remain in detention on Ellis Island in order to challenge the constitutionality of his deportation. ${ }^{86}$ Turner agreed. He strongly believed he would lose the case, but stated "I would gladly stay here till I rot . . . if by so doing I can assist my American friends in their fight for the vital principle of liberty involved." 87

The Free Speech League asked Clarence Darrow to represent Turner and raised money for the defense, holding rallies in Turner's honor and delivering speeches on how Turner's deportation threatened freedom of speech. ${ }^{88}$ They argued that Turner was a nonviolent, philosophical anarchist, who posed no threat to the United States or its residents. ${ }^{89}$

Darrow asserted that the Alien Act violated the First Amendment and had turned immigration officials into censors, contending that the exclusion and deportation of anarchists not only posed a threat to anarchists but to all Americans' freedom of speech and its value. ${ }^{90}$ To deport Turner for his mere belief in anarchism undermined the United States' purported identity as a nation tolerant of free thought and

83. John Turner to be Deported, N.Y. TRIB., Oct. 25, 1901, at 8; see Transcript of Record at 5-6, United States ex. rel. Turner v. Williams, 194 U.S. 279 (1904) (No. 561) (Testimony of Inspectors John J. McKee and Joseph Weldon, from the Minutes of Board of Special Inquiry convened at U.S. immigration Station, Ellis Island, on Oct. 23, 1904).

84. See Transcript of Record at 5-6, United States ex rel. Turner v. Williams, 194 U.S. 279 (1904) (No. 561).

85. Free Speech League lawyer Hugh $O$. Pentecost volunteered to represent Turner and immediately filed a writ of habeas corpus on behalf of Turner, calling for his release. See Transcript of Record at 16, United States ex. rel. Turner v. Williams, 194 U.S. 279 (1904) (No. 561) (Petition of John Turner for a writ of habeas corpus, filed by Pentecost \& Campbell, Attorneys for John Turner, on Nov. 11, 1903).

86. GoldMAN, supra note 3, at 347-48.

87. Operation of Our New "Alien and Sedition Laws," The PuBlic, Nov. 21, 1903, at 526 (recounting Turner's testimony in an Immigration Hearing before Commissioner William Williams); Russian Methods in America, FREE Soc'Y, Nov. 29, 1903, at 2.

88. See, e.g., Against Anti-Anarchy Law, Cooper Union Filled, N.Y. DAILY TrIB., Dec. 4, 1903, at 6; Seek Appeal For Turner: Central Union to Ask for Funds to Carry Up Deportation Case, N.Y. TMmES, Feb. 29, 1904, at 10.

89. 2 EMMA GOLDMAN: A DOCUMENTARY HISTORY OF THE AMERICAN YEARS: MAKING SPEECH FREE 1902-1909, at 121 n. 2, 122 n. 11 (Candace Falk et al. eds., 2005).

90. See Transcript of Record at 40-41, 76-77, United States ex. rel. Turner v. Williams, 194 U.S. 279 (1904) (No. 561) (Brief and Argument of Appellant). 
expression. Darrow compared the Alien Act of 1903 to the reviled Alien Act of 1798. ${ }^{91}$ Representing Commissioner Williams and defending the constitutionality of the Alien Act, future Supreme Court Justice James Clark McReynolds dismissed Darrow's First Amendment argument stating that, as a foreigner, Turner had no First Amendment rights. ${ }^{92}$ $\mathrm{He}$ insisted that Turner's deportation was strictly an immigration issue and thus, only immigration law applied. McReynolds declared Turner's deportation under the Alien Act to be a constitutional exercise of Congress's plenary power and of the right of the United States to selfpreservation. ${ }^{93}$

While the Turner case would help raise public consciousness of the importance of preserving and protecting free expression, Turner was right; he did lose his case. The Supreme Court upheld his deportation and the constitutionality of the Alien Act, deferring to Congress's plenary power to exclude foreigners as it wished, and declaring that foreigners held no rights under the Constitution. ${ }^{94}$ The Court also dismissed any distinction between philosophical and violent anarchists, relying on Congress's determination that anarchism advocated in any form presented a bad tendency, as all anarchists were dangerous to the public welfare. ${ }^{95}$ Despite their loss, anarchists used the publicity to encourage membership in the Free Speech League and support for their cause. Editor of Discontent, James F. Morton, Jr. wrote to his readers:

[T]he decision of the Supreme Court against John Turner destroys even the faintest hope for free speech in this country, until a radical change in public sentiment is brought about. This now becomes the paramount issue, and the only possible hope for our civilization. Without free speech a country is not fit to live in; and all hope of progress is destroyed. This does not concern only Anarchists, but all decent Americans. Now is the time to get to work. Join the Free Speech League at once; and help it all you can. ${ }^{96}$

The Turner case was a significant step in encouraging a free speech consciousness and in garnering sympathy for anarchists, transforming

91. Id. at 107 (Brief and Argument of Appellant).

92. Id. at 21-24 (Brief of Appellee).

93. See id. at 12-16.

94. See United States ex. rel. Turner v. Williams, 194 U.S. 279, 289-92 (1904).

95. See id. at 294.

96. See James F. Morton Jr., The DemonstratoR (Home, Wash.), June 8, 1904, at 1, a publication formerly known under the name DISCONTENT. 
them into free speech defenders. Some newspapers openly criticized Turner's deportation and the United States' War on Anarchy, arguing that anti-anarchist measures were counterproductive. An editorial in Louis. F. Post's Chicago progressive paper The Public declared that governmental repression "[had] done more to advertise and propagate anarchist doctrines than ten thousand undisturbed lectures could have done; for these attempts to deport a thinker and to suppress a meeting have aroused to some extent the traditional believers in free speech in America." 97

\section{AMERICA'S ANTI-ANARCHISM CONTINUES: THE EMERGENCE OF A FREE SPEECH CONSCIOUSNESS}

Over the next few years, anarchists continued to hold meetings, attend lectures, and read anarchist newspapers. Emma Goldman's new anarchist journal, Mother Earth, featured articles on anarchism and philosophy, as well as calls to join and donate to the Free Speech League. ${ }^{98}$ Law enforcement and local officials, however, continued to shut down these meetings, prevent lectures, and suppress newspapers. ${ }^{99}$ Their efforts did not go unnoticed, particularly by the mainstream press, which began to criticize these anti-anarchist tactics as violating freedom of expression. The New York Times editors challenged the reasonableness of convicting philosophical anarchists, creating their own constitutional speech test:

Unless we take away the presumption [of innocence] we shall find it very difficult to convict an anarchist unless there has been some actual overt act in the way of an attempt at murder, or at least a direct incitement and instigation to a particular murder. One can hardly imagine the conviction of an anarchist simply for being an anarchist under laws which would not abridge freedom of speech and of the press. ${ }^{100}$

97. Too Officious, THE PUBLIC, reprinted in THE DEMONSTRATOR, Mar. 23, 1904, at 7.

98. See Theodore Schroeder, On Suppressing the Advocacy of Crime, MOTHER EARTH, Jan. 1907, at 7. See generally ANARCHY! AN ANTHOLOGY OF EMMA GOLDMAN's MOTHER EARTH (Peter Glassgold ed., 2000).

99. See, e.g., Police had a "Tip." Heard Paterson Anarchists Were Planning "Demonstration" Here, N.Y. TRIB., Mar. 29, 1908, at 7; "Reds" Gathered In. Berkman and Goldman: Police Break Up Big Meeting of Anarchists-No Resistance, N.Y. TRIB., Jan. 7, 1907 , at 1.

100. Whipping Anarchists, N.Y. TIMES, Aug. 15, 1906, at 6. 
In 1908, thousands gathered in New York City's Union Square for a large unemployment protest demonstration. Organizers had applied for a permit, but their application was denied by the Park Commissioner, who stated, "[T] not for the purpose of holding mass meetings." 101 As a crowd of men and women demonstrated in Union Square, police began to forcibly clear them away. A protestor confronted Police Inspector Max Schmittberger and stated, " $[\mathrm{My}]$ name is Bruno Zimm. I'm a sculptor and I am here in the interest of American citizens who are denied the right of free speech." Zimm pulled out of his pocket a copy of the Constitution, and waving it, he stated, "I demand that you abide by the fundamental law of the land. I stand on the First Amendment. Let me read it."102 Shaking his nightstick in Zimm's face, Schmittberger shouted, "Now, this club for the time being is mightier than the Constitution. You beat it, my friend, and beat it quick!"103 And Zimm did. Afterward, Hildegard Hawthorne, granddaughter of Nathaniel Hawthorne, criticized police behavior in clearing the square, writing to the New York World:

[T]he bullying of the crowd by the city's servants, hired to maintain peace and not to suppress the freedom each citizen is entitled to, should not be tolerated. There can be no surer way to incite anarchy than to make the people feel that the law is their enemy in the rightful exercise of their privileges as American citizens. ${ }^{104}$

One striking example of Hawthorne's warning occurred a few weeks later, when Emma Goldman gave a lecture entitled "Patriotism" in San Francisco. Army Private William Buwalda attended in uniform, and afterward, he thanked Goldman for her speech and shook her hand. Audience members cheered. ${ }^{105}$ Buwalda, however, was placed under military arrest and tried in a court-martial for a violation of the 62nd Article of War for his applause and tacit approval of Emma Goldman's "attack and criticism on government."106 Buwalda was convicted and sentenced to five years in Alcatraz, later reduced to three years by

101. Parks Are Not for Meetings, He Says, N.Y. WoRLD, Apr. 29, 1908, at 2.

102. Reds Plot Massacre of Police, Throw Bomb in Union Sq.; Man Killed, N.Y. WorLD, Mar. 30,1908 , at 3.

103. Id.

104. The Right Peacefully to Assemble, N.Y. WoRLD, Apr. 2, 1908, at 6.

105. See GolDMAN, supra note 3 , at 428 .

106. Transcript of Court-martial of William Buwalda, First Class Private, Company A, 1st Battalion of Engineers, May 14, 1908 (on file with the National Archives and Records Administration, Washington, D.C., contained in Judge Advocate General Record Group 153, Box 12, File 56990, Entry 17). 
Commanding Army General Frederick Funston. ${ }^{107}$ The Free Speech League rushed to his defense, while some members of the public were shocked, unable to understand how a mere handshake could lead to a three-year prison term. Editors at the Nation magazine wrote:

Now nobody is more opposed to anarchists then the Nation; but it is news to us that attending a meeting is a military crime .... [U]nless the court wishes to make an anarchist out of him ... the case stands as another example of our national hysteria over what is a state of mind, and not in itself a crime. ${ }^{108}$

This was a distinction between ideology and crime that law enforcement, Congress, and the courts had refused to make.

William Dudley Foulke, a progressive reformer and Commissioner of the Civil Service, wrote to the Attorney General shortly after Buwalda's sentence. Foulke argued that people "have as good a right to be anarchists as you and I have to be Republicans." 109 He also warned against the War on Anarchy. Echoing The New York Times, Foulke wrote "[le]gislation against any class of opinions, short of incitement to crime, may be made the entering wedge for the gradual extension of the suppression of free speech on other subjects."110 Public outrage at Buwalda's treatment led many, including General Funston, to urge President Roosevelt to pardon him; Funston made assurances that Buwalda would fall in line and never see Emma Goldman again. ${ }^{111} \mathrm{He}$ was wrong. After his pardon and discharge, Buwalda wrote to the War Department returning the medal he had received for service in the Philippines. Buwalda would later meet with Goldman and explain that his experience had only served to raise his consciousness and to reinforce her criticisms. ${ }^{112}$ Buwalda then escorted Goldman to a meeting where she was to deliver another lecture. While walking, they were

107. See Comment, 86 The NATION 502, 502 (1908).

108. Id.

109. Letter from William Dudley Foulke, Comm'r, Civil Service Commission, to Charles Joseph Bonaparte, U.S. Att'y Gen. (Apr. 10, 1908), microformed on The Emma Goldman Papers Collection, Reel 1 (Chadwyck-Healey 1990).

110. Id.

111. Letter from Frederick Funston, Commanding General, California, to Fred Ainsworth, Adjutant General, U.S. Department of War (June 30,1908), microformed on The Emma Goldman Papers Collection, Reel 1 (Chadwyck-Healey 1990).

112. See GolDMAN, supra note 3 , at 446. 
arrested; this time, Buwalda was charged with associating with dangerous criminals. ${ }^{113}$

In 1909, Goldman met Alden Freeman, a wealthy member of the elite New Jersey Society of Mayflower Descendants. When police shut down a Sunday lecture series after Goldman began to speak, Freeman, an audience member, was outraged. Finding no incitement to violence and viewing the police actions as violating freedom of speech, Freeman invited Goldman to speak at a Mayflower Society luncheon.114 Impressed with Freeman, Goldman accepted the invitation but was not well-received at the luncheon. ${ }^{115}$ Initially, the Society voted to expel Freeman for inviting Goldman. ${ }^{116}$ Society members later came forward and exonerated Freeman as a free speech defender. One member commented, "[a]fter we had got his point of view and realized that he was not an anarchist but a champion of freedom of speech, we shook hands with him, and that was the end of the matter."117

Freeman continued his free speech efforts and organized an Open Forum in commemoration of the 100th Anniversary of Thomas Paine's birth, inviting the President of the Free Speech League, Leonard D. Abbott, to deliver a lecture entitled "Suppression of Free Speech in the United States."118 However, police prevented Freeman, Abbott, and Goldman from entering their reserved lecture hall in East Orange, New Jersey. ${ }^{119}$ Without protesting, Freeman declared "the lecture will be held in my barn," and invited the speakers and audience to follow him to his barn on the Freeman grounds; 300 men and women attended the forum. ${ }^{120}$

Freeman introduced Goldman, emphasizing the importance of allowing her to speak:

I am glad that East Orange and New Jersey have the opportunity to observe that Miss Goldman has neither hoofs nor horns, and that she is not a witch riding on a

113. See id. Outside the lecture hall in San Francisco, Buwalda was arrested with Emma Goldman, who was arrested for conspiracy to make threats and disturbing the peace; Buwalda was released upon arrest, but Goldman was formally charged.

114. See id. at 453. See generally Emma Goldman in Society: Fashionable New Jersey Women Gasp at Unexpected Guest at Mayflower Luncheon, L.A. TIMES, May 22, 1909, at I1.

115. See Goldman, supra note 3 , at 453.

116. Emma Goldman to Meet Society in Orange Again, N.Y. WoRLD, June 7, 1909, at 2.

117. Id.

118. See Goldman Talk in a Barn, N.Y. TIMES, June 8, 1909, at 16.

119. See id.

120. Emma Goldman, Driven to Talk in a Barn, Is Jeered, N.Y. WoRLD, June 9, 1909, at 1. 
broomstick . . . . I have too much confidence in the fairmindedness of my neighbors to fear they will permit Emma Goldman to share the fate of Hypatia. ${ }^{121}$

Responding to some jeers in the audience, Goldman chided the hecklers and praised Freeman:

If you who are jeering had paid admission you would consider it your duty to behave yourselves and extend the ordinary courtesies to a speaker. I am here because of the kindness of a man who had the courage to welcome free discussion of a subject vital to the uplifting of humanity. ${ }^{122}$

The crowd quieted down and let Goldman speak. Freeman would later participate in a Free Speech League rally held at Cooper Union in New York City to protest police harassment of Goldman. ${ }^{123}$

Not only had anarchists become challengers to suppression and champions of free speech, but they also embraced this new identity. When police failed to raid another one of Emma Goldman's lectures, a disappointed audience member remarked, "[i]f the police are going to let us conduct our meetings as we want to, there won't be any use of being anarchists at all."124

Throughout 1909, Goldman and the Free Speech League worked together to challenge police suppression of speech in various cities in what they referred to as "free speech fights." 125 These fights began in Philadelphia, when police informed Goldman that she could only speak after the Director of Public Safety had reviewed copies of the speeches beforehand. Goldman refused and applied for an injunction arguing that this demand was a prior restraint and an infringement on freedom of speech. ${ }^{126}$ Goldman recounted in her autobiography: "I had no faith in legal procedure, but my friends argued that if I refused, the police would undoubtedly continue their tactics, whereas a legal fight would focus public attention on their Russian methods of trying to gag me."127

\footnotetext{
121. Id.

122. Id.

123. Goldman Champions Win the East Side, N.Y. TIMES, July 1, 1909, at 18.

124. Emma Goldman Unmuzzled, N.Y. TIMES, July 24, 1909, at 4.

125. See GoLdMAN, supra note 3, at 459; WEXLER, supra note 2, at 178.

126. Bill Lynskey, "I Shall Speak in Philadelphia": Emma Goldman and the Free Speech League, 133 PA. MAG. HIST. \& BIOGRAPHY 167, 168 (2009).

127. GOLDMAN, supra note 3 , at 456-57.
} 
Goldman was right. A Philadelphia judge denied her injunction. ${ }^{128}$ Yet the publicity resulting from the Philadelphia free speech fight drew the attention of many Americans, raising free speech consciousness, garnering sympathy for the persecuted Emma Goldman, and solidifying her image and that of American anarchists as free speech defenders.

\section{THE LEGACY OF AN ASSASSINATION'S AFTERMATH}

In the decades that followed, New York's Criminal Anarchy Act served to suppress various socialists and communists, most notably American communist Benjamin Gitlow, who unsuccessfully challenged the constitutionality of the Criminal Anarchy Act in 1925.129 The Free Speech League, the United States' first free speech organization, would defend radicals, war resisters, and pacifists throughout World War I and would influence Roger Baldwin in founding the American Civil Liberties Union in 1920.130 The 1903 Alien Act's anti-anarchist provision and the John Turner case would pave the way for future ideological restrictions and the constitutional precedent to support them. In 1918, Congress eliminated the landing limits, permitting the deportation of foreigners no matter how long they had resided in the United States. ${ }^{131}$ This elimination of landing limits enabled the mass deportation of foreigners in the wake of Attorney General A. Mitchell Palmer's raids and arrests of anarchists and radicals in 1919.132 Emma Goldman was one of these deportees. Despite having lived in the United States for over thirty years, Goldman was deported to Russia with 249 foreign radicals on the S.S. Buford, the "Red Ark."133

The McCarran Act of $1950^{134}$ and the McCarran-Walter Act of $1952^{135}$ added anticommunist exclusionary provisions, which served as the legal basis to deny visas and entry to Chilean poet Pablo Neruda,

128. Goldman v. Reyburn, 18 Pa. Dist. R. 883, 884-85 (1909).

129. See Gitlow. v. New York, 268 U.S. 652 (1925) (upholding the constitutionality of New York's Criminal Anarchy Law, and also establishing the incorporation of the First Amendment through the Fourteenth Amendment to apply to the states).

130. RABBAN, supra note 12, at 76; SAMUEL WALKER, IN DEFENSE OF AMERICAN LIBERTIES: A HISTORY OF THE ACLU 22 (1990).

131. Act of Oct. 16, 1918, ch. 186, 40 Stat. 1012 (excluding and expelling from the United States aliens considered to be anarchists or identified with similar ideologies).

132. See RoBERT JUSTIN GOLDSTEIN, POLITICAL REPRESSION IN MODERN AMERICA: FROM 1870-1976, 139-58 (2001).

133. Also referred to as the "Soviet Ark" See Soviet 'Ark' Dumps Reds' In Finland: Berkman and Emma Goldman Head Parade Down Gangplank at Hango; Attack Feared, N.Y. TRIB., Jan. 18, 1920, at 1.

134. Internal Security Act of 1950 , ch. $1024 \S 22,64$ Stat. 987, 1006-07.

135. McCarran-Walter Act, ch. 477, § 212(a)(27), 66 Stat. 163, 184 (1952). 
Colombian writer Gabriel García Márquez, British novelist Graham Greene, and even world-renowned British-born film star Charlie Chaplin. ${ }^{136}$ In 1969, the State Department denied Belgian Marxist economist Ernest Mandel entry to the United States to deliver a series of lectures and participate in conferences at U.S. universities. ${ }^{137}$ In Kleindienst $v$. Mandel, 138 the Supreme Court upheld his exclusion by relying on United States ex rel. Turner $v$. Williams as precedent. ${ }^{139}$ Over three decades later, Mandel would serve as precedent to support a visa denial to bar entry to Swiss Islamic scholar Tariq Ramadan in 2004, under ideological restrictions of foreigners within the Patriot Act. ${ }^{140}$ As Congress swiftly passed the Patriot Act in the wake of the September 11, 2001 terrorist attacks, ${ }^{141}$ the United States would declare a War on Terror and would seek assistance and cooperation from other nations in a global effort to prevent terrorism around the world. ${ }^{142}$

A century earlier, the United States was forced to tackle the anarchist problem and entered the global War on Anarchy, suppressing expression and passing laws to exclude and expel foreign anarchists. Yet, these efforts only served to transform anarchists from violent criminals to free speech defenders. Thus, the anarchists that the public called on the government to suppress would soon become the anarchists the public sought to protect against suppression.

Passed in the aftermath of President McKinley's assassination, the anti-anarchist provisions of the Alien Act of 1903 were the first set of ideological restrictions of foreigners in the United States. The provisions were not only part of the reactionary measures taken in the wake of a national tragedy, but they also reflected the xenophobic nature of

136. See Graham Greene Visa Held Up for Inquiry, N.Y. TIMES, Feb. 3, 1952, at 1; James Schwartz, The McCarren-Walter Act: Legislation Under Fire, WASH. POST, Nov. 13, 1985, at A23. For a list and detailed description of these exclusions see Ideological Exclusion Timeline, American Civil Liberties Union (July 24, 2006), http://www.aclu.org/ safefree/general/26213res20060724.html.

137. See Justices to Weigh Ban on Marxists; Mitchell's Denial of Visa to Belgian is Challenged, N.Y. TIMES, Jan. 11, 1972, at 43.

138. Kleindienst v. Mandel, 408 U.S. 753 (1972).

139. See id. at 762 .

140. See American Academy of Religion v. Chertoff, No. 06 Civ. 588, 2007 WL 4527504 (S.D.N.Y. Dec. 20, 2007).

141. The Patriot Act was passed in 2001 as the "Uniting and Strengthening America by Providing Appropriate Tools Required to Intercept and Obstruct Terrorism (USA PATRIOT ACT) Act of 2001" Pub. L. No. 107-56, 115 Stat. 273. See also, e.g., Robin Toner \& Neil A. Lewis, A Nation Challenged: Congress; House Passes Terrorism Bill Much Like Senate's, but with 5-Year Limit, N.Y. TIMES, Oct. 13, 2001, at B6.

142. See, e.g., President's State of the Union Message to Congress and the Nation, N.Y. TIMES, Jan. 29, 2003, at A12 (providing a transcript of President George W. Bush's speech describing antiterrorism efforts and intentions). 
antiradicalism in the United States, as well as the failure to separate ideology from action. The Alien Act would provide the blueprint for ideological exclusion and deportation throughout the twentieth century. Each new additional exclusion or deportation category of foreigners corresponded to the internal suppression and ideological conflicts during the Cold War, and later the War on Terror, and would reveal a profound and persistent fear of foreigners and of freedom of speech in America. 
